\title{
Um “Choque de ordens": uma análise sobre o controle do espaço público na orla carioca
}

Patrícia Silveira de Farias

Este trabalho se refere a uma pesquisa de pós-doutorado, realizada no âmbito do Programa de Pós-Doutorado em Cultura Contemporânea da UFRJ (PACC/UFRJ)1, durante os anos de 2011 e $2012^{2}$. Seu objetivo geral é investigar dois eixos de questões o primeiro, ligado à área de estudos urbanos, sobre a conexão entre as noções de espaço público e esfera pública, no contexto sócio-histórico do Rio de Janeiro das primeiras décadas do século XXI. O segundo, que se refere à análise de políticas públicas, sobre a percepção e participação dos diferentes agentes públicos na execução destas políticas. Para isso, voltei a um campo que já conhecia de estudos anteriores: a orla carioca ${ }^{3}$. Nela, vinha ocorrendo um processo de ordenamento institucional que foi sintetizado mais recentemente pelo conjunto de ações chamado sugestivamente de "Choque de Ordem". A metodologia incluiu levantamento e análise documental, de leis e ordenamentos federais, estaduais e municipais, além de observação participante, dezenas de conversas informais e entrevistas em profundidade com agentes públicos estaduais e municipais, além de banhistas e trabalhadores da praia (10 entrevistas com agentes e $10 \mathrm{com}$ freqüentadores, sendo cinco com trabalhadores locais e os outros cinco, com banhistas).

\footnotetext{
${ }^{1}$ Agradeço a supervisão atenta e gentil da Profa. Ilana Strozenberg, coordenadora do Programa de Pós-Doutorado do PACC/UFRJ, e a acolhida da Profa. Heloisa Buarque de Hollanda, coordenadora geral do PACC.

${ }^{2}$ A pesquisa contou com o auxílio das assistentes de pesquisa Maria Virgínia Botelho Rodrigues e Verônica Dutra, através de bolsas de Iniciação Científica (UFRJ e Faperj), a quem agradeço a colaboração. Uma versão anterior deste trabalho foi apresentada no XII Encontro da Brazilian Studies Association (Brasa), realizado em Londres, em agosto de 2014.

${ }^{3}$ Cf. Farias, 2003.
}

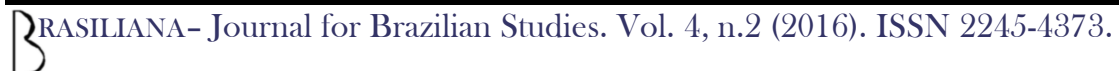


Na pesquisa anterior, me chamara a atenção o repetido mantra “a praia é um espaço democrático", com que vários cariocas me brindavam ao falar da orla. Quis saber o que isto significava para eles, e portanto, também, o que significava isto pra cidade. Recortei este grande tema entrecruzando-o com a temática étnico-racial, pois me parecia que as duas "democracias" - a do espaço e a racial - apareciam juntas: "ah, a praia é democrática, todo mundo quer ficar preto, não importa se você é rico ou pobre, branco ou preto".

Associei esta noção conectada à praia com a análise de Turner (1969) sobre a experiência de igualdade hierárquica - "communitas" - que os indivíduos de algumas culturas experimentavam em rituais coletivos. Desta forma, a praia se tornava este lugar em que as hierarquias - de classe social e de cor - pareciam desaparecer. Desta forma, a democracia afirmada no espaço praia vinha associada à idéia de igualdade.

Entretanto, se havia este discurso que perpassava as falas dos mais diversos entrevistados, acabei por perceber que, subjacente a ele, havia outra questão que também seria importante no atual trabalho: que a noção de democracia era uma noção em disputa, e, a depender do grupo que a proclamava, ganhava significados diversos; assim, em sua forma dominante, me parecia que a noção de igualdade se desdobrava incisivamente em um certo ethos hedonista, em que a idéia é que a praia era democrática não só porque nela todos estariam em estado de "communitas", igualados pela pouca vestimenta e por uma espécie de suspensão das hierarquias existentes e estruturantes da cidade. Mas também porque a praia estava associada à busca do prazer, e à noção de que nela você, indivíduo, poderia fazer o que quisesse. Neste sentido, todos experimentariam ali uma espécie de "igualdade de oportunidades", em que a liberdade individual e a procura do prazer eram os pontos mais importantes. 
Isto era verdade principalmente para grupos pertencentes a camadas médias e altas, brancas e moradoras da parte mais "nobre" da cidade 4 . Enquanto isso, a mesma idéia de "praia democrática" funcionava, para os extratos mais populares, moradores de regiões menos valorizadas, e também para pessoas negras, como um sinônimo de exercício do direito de ir e vir. Desta forma, na idéia de igualdade vinha embutida uma outra noção, a de igualdade de direitos - o direito de circular e o direito de ali estar, usufruindo de um local público, ou seja, em princípio, de todos. A liberdade então aparecia dentro deste espectro. Já para alguns autointitulados "morenos, mestiços", em processo de ascensão social, este lugar era considerado "democrático", pois significava a confirmação de que "subiram na vida". Nesta direção, o local era democrático pois representava a possibilidade de expressar mobilidade social.

Enfim, verifiquei neste estudo que, na verdade, havia limites de cor e de classe, para este exercício de liberdade individual, para a mobilidade urbana e para a ascensão social - para a democracia, enfim. Diversas estratégias eram - e são - postas em prática pelos grupos dominantes para cercear este "ir e vir", desde a busca e o incentivo à intervenção policial pura e simples até a evitação e isolamento forçados, no espaço da praia, aos grupos com menor status social.

Isso foi em 2000. Já naquele trabalho eu sinalizava que havia em andamento um processo de maior institucionalização e controle do espaço, por parte do poder público, particularmente a prefeitura do Rio, a partir da padronização dos quiosques de venda de bebidas e alimentos, de um maior rigor na fiscalização dos transportes e na vigilância policial. No início dos anos 10 do século XXI, este processo se encontrava bem mais adiantado. Uma forma possível de sinalizar e discutir este novo momento se apresenta através de alguns cenários. Visualizaremos alguns deles a seguir.

\footnotetext{
${ }^{4}$ Para uma análise das hierarquias de espaços urbanos no Rio de Janeiro, cf. Farias e Cecchetto, 2009.
} 


\section{Palco A: Iemanjá}

Primeira informação: é preciso comprar uma camiseta do evento para poder ir na carreata junto com os outros. Lastimavelmente só soubemos disso quando chegamos ao Mercadão de Madureira ${ }^{5}$, de onde partiam os ônibus, com religiosos, lojistas e interessados em participar da Festa de Iemanjá no Posto 4 de Copacabana, zona sul do Rio de Janeiro. O evento, promovido pelos lojistas do Mercadão e pela Associação das Baianas do Acarajé do Rio de Janeiro, com apoio da Prefeitura do Rio de Janeiro, teve início em 2003, para agradecer à divindade o ressurgimento do Mercadão, destruído pelo fogo em 2000 e reinaugurado em 2001; em 2007, por iniciativa do então vereador Átila Nunes Neto, o prefeito à época, César Maia, instituiu pela lei 4.516 de 25 de maio, o dia 29 de dezembro no calendário oficial da cidade do Rio de Janeiro como o Dia de Iemanjá. Desde então, é realizado anualmente ${ }^{6}$.

A festa é organizada em cinco etapas. Na primeira, chamada no site dos promotores do evento como "preâmbulo da festa", há a arrecadação de presentes e pedidos dos visitantes do Mercadão e dos próprios lojistas, que são em seguida depositados em um barco de um metro. O processo dura todo o mês de dezembro, até o dia 29. Neste dia, ocorre a procissão, que aglutina as quatro outras etapas: a Concentração no Mercadão das pessoas que irão participar da festa; a carreata até a praia de Copacabana; e, afinal, a cerimônia em si, com rituais religiosos na praia que se encerram com uma revoada de pombos brancos. Seguem-se os "shows culturais", com

\footnotetext{
${ }^{5}$ Situado no bairro de Madureira, zona norte do Rio de Janeiro, o Mercadão foi inaugurado no atual local em 1959. Hoje, conta com 580 lojas de artigos diversos e considerado um dos grandes pólos comerciais da cidade.

${ }^{6}$ Informações constantes do site do Mercadão de Madureira: www.mercadaodemadureira.com.
} 
apresentação de "grupos folclóricos focada em rituais de nossos ancestrais Afrodescendentes" (cf. site do Mercadão de Madureira).

No dia 29/12/2011, lá estávamos, observando as doações dos fiéis: barcos em miniatura, com perfumes, espelhos, sabonetes, flores, bilhetes, colares, frutas, retratos, pentes, tudo para agradar àquela que é considerada "Mãe de todos os oris"7. Havia

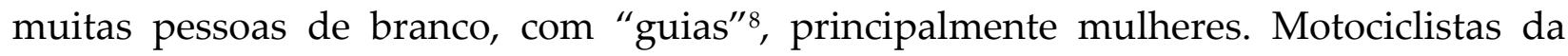
Guarda Municipal faziam a escolta dos ônibus com os grupos que iam ao evento. Acompanhávamos um caminhão que ostentava uma imagem de dois metros de altura da Rainha das Águas. Dois ônibus foram destinados apenas a mães e pais de santo, enquanto outros se direcionavam aos fiéis de variados terreiros do Rio de Janeiro. Havia ainda um caminhão com carro de som e inúmeros carros particulares. Repórteres de emissoras de TV e vários participantes documentavam através de filmagens e fotos todas as etapas.

A saída do Mercadão atrasou, e ao invés de 15 horas, todos saíram por volta das 16 horas, chegando à praia às 17:35h. Não houve reclamação; dentro dos ônibus, pessoas cantavam "pontos" (músicas em homenagem às divindades), comiam, conversavam e bebiam. Como comentou um fiel, “até Exu bebe, isso não é falta de respeito, as entidades sabem da intenção de cada um".

A chegada à praia foi organizada novamente pela Guarda Municipal e seus batedores, pois o trânsito havia ficado lento. Estes últimos se encarregaram de interromper o trânsito para que a imagem e seus fiéis atravessassem a rua, enquanto os guardas demarcavam o local onde os ônibus deveriam estacionar. Gente de várias

\footnotetext{
${ }^{7}$ Ori é uma divindade que expressa a individualidade de que é dotado cada ser humano.

${ }^{8}$ Tais cordões apresentam contas dispostas em determinada ordem, e cada um deles representa o orixá ao qual seu portador é filho; as guias servem, portanto, de identificação para aqueles que são iniciados nas religiões de matriz afro. Servem também de proteção contra energias consideradas ruins e símbolo da ligação entre o devoto e a divindade que o protege, entre o mundo profano e o sagrado, enfim.
}

RRASILIANA- Journal for Brazilian Studies. Vol. 4, n.2 (2016). ISSN 2245-4373. 
localidades do Rio ladeavam a imagem, cantando; alguns estrangeiros também dançavam. Quiosqueiros ofertavam produtos para a entidade, dirigindo a Iemanjá apelos de sorte e sucesso, pois, como um deles explicou, não gostariam de "ficar em dívida com ninguém", e dependiam do bom tempo para ter um bom dia de trabalho. Famílias inteiras estavam presentes.

Na areia, uma tenda abrigava uma miniarquibancada, instrumentos de culto e vários pais e mães de santo. Todos os presentes começaram a cantar; alguns distribuíram imagens de Iemanjá àqueles considerados "filhos" da divindade.

Após muita cantoria, formou-se uma fila para a colocação dos presentes e dos barquinhos nos barcos maiores, a começar pelos lojistas, os líderes espirituais e os pescadores, e a seguir os demais fiéis. Os pescadores da colônia localizada no Posto 6 levaram os barcos ao mar. Nestes, somente pessoas credenciadas podiam entrar.

Grupos heterogêneos participavam igualmente do culto e das oferendas. Turistas - facilmente reconhecíveis pelo protetor solar, pelos chapéus e bonés, pela postura de esconder objetos de valor como câmeras e relógios; umbandistas e pessoas do candomblé, assim como pessoas que se consideravam "espiritualistas", mas que “acreditavam em Iemanjá", e também católicos.

Entre os trabalhadores, os salva-vidas eram os mais tensos; olhos postos no mar, tentavam ver além da multidão que se concentrava nas areias, e que, para eles, atrapalhava a visão e a atuação nos salvamentos. Também se ocupavam em prestar atenção naqueles que, nas águas, faziam suas oferendas diretamente à Rainha do Mar. Nenhum deles quis dar entrevistas. A Guarda Municipal buscava contato com os salvavidas a cada atendimento; isto porque, segundo relataram, seriam os responsáveis pelo acionamento de uma ambulância, caso necessário, e de sua rápida chegada ao local ${ }^{9}$.

\footnotetext{
${ }^{9}$ No caso deste evento, soubemos que até o fim da festa apenas duas pessoas haviam sofrido cortes, sem gravidade, e portanto não foi necessária ambulância.
} 
Enquanto isso, a Polícia Militar mediava conflitos entre os banhistas e auxiliava os guardas municipais na organização do trânsito. O grupo de motociclistas/batedores realizava a escolta da imagem de Iemanjá do Mercadão até a praia.

Também os ambulantes estavam ocupados; credenciados disputavam com clandestinos a clientela, pois os guardas estavam atentos ao evento e não conseguiam reprimir os ilegais - caso de um pipoqueiro, por exemplo, e de um vendedor de picolés que viera especialmente por conta da festa.

Ao final do evento, cerca de $21 \mathrm{~h}$, a saída para muitos foi esperar cerca de 40 minutos por condução. Havia ainda muita gente; os pontos de ônibus estavam lotados; uma grande quantidade de vans, várias delas não legalizadas, e que por isso chegavam e saíam muito rápido, transportava fiéis, que se dispersavam, cansados e tranqüilos, alguns, ainda cantando.

\section{Palco B: Os Planos}

O status das praias marítimas está estampado na Constituição de 1988, onde é indicado que a União tem a posse legal da orla - sendo ela um "bem comum", ou seja, um bem pertencente à população em geral - e designando a Marinha como sua administradora. Enquanto isso, a Prefeitura do município faria o gerenciamento da parte urbanística. Quanto ao Governo estadual, cabe a ele prover os serviços de saneamento público que incidirem sobre este espaço (cf. Constituição da República Federativa do Brasil de 1988, Art.20, inciso VII). O Estado também seria o responsável pela segurança dos frequentadores, o que seria conseguido através tanto da presença de policiamento militar na região, quanto dos salva-vidas.

$3^{\text {RASILIANA- Journal for Brazilian Studies. Vol. 4, n.2 (2016). ISSN 2245-4373. }}$ 
É justamente este esquema de atuação “em camadas" que vem sendo alterado por uma nova perspectiva tanto diante da cidade, quanto da praia, que pode ser sintetizada, como veremos, pelo encolhimento da atuação do Governo Estadual e o crescimento do controle por parte do Município. Neste sentido, é importante sinalizar, ainda nos anos 90, o surgimento da Secretaria Nacional de Segurança Pública, a Senasp, que irá estimular a criação de Guardas Municipais em todo o país, com as quais estabelecerá convênios em ações de segurança, policiamento e formação de pessoal.

Neste bojo se situa a criação dos Planos de Segurança Pública 2000 e 2002, ambos reforçando a inserção dos municípios nas políticas de segurança. Particularmente este último, o de 2002, irá propor uma "modelagem desejável" da Guarda Municipal, compreendida como formada por "gestores e operadores da segurança pública, na esfera municipal" e, enfim, como "solucionadores de problema" (apud Mello, 2011:63). O Plano também propõe a instalação de centrais de monitoramento que integrem os diversos níveis de polícia, o que ocorrerá em 2010 no Rio de Janeiro.

Mello (2011), em seu estudo sobre os conflitos e papéis de guardas municipais e camelôs na cidade Niterói (RJ), comenta que as atribuições contidas no Plano, no que se refere à Guarda, a conectam ao modelo de "policiamento comunitário", mais próximo dos cidadãos. Seria então o Plano uma forma de conectar estas experiências a um novo modo de pensar polícia no Brasil. Entretanto, como alerta Kant de Lima (apud Mello, 2011), essa "política induzida" a partir da promessa de recursos federais advindos da Senasp via convênios, cai num terreno complexo, em que pelo menos duas visões conflitantes de segurança pública se enfrentam: uma, tradicional, de cunho repressivo, calcada em "noções militares de combate à desordem e ao crime", e por um entendimento da necessidade de manter esta ordem por força do medo e da punição (p.13, op. cit.). Outra, a de que a ordem pública é mantida através da construção de 
consenso por parte dos grupos envolvidos e daí advém sua legitimidade; por isso seria obedecida.

Dentro desta lógica que promove a ampliação da ação municipal nas políticas públicas, já nos primeiros anos do século XXI, um projeto instituía uma parceria entre o poder municipal e uma empresa, a Orla Rio, para ordenar e modernizar especificamente o comércio nas praias. A padronização de quiosques daria o tom, com a construção de 309 unidades do Leme ao Pontal. Comenta Reginensi (2008) que a partir daí se pode visualizar a emergência de uma nova linguagem utilizando a terminologia de 'cidade marketing'”' (p.156).

Em 2007, um novo evento vai ser articulado a este esforço do poder público municipal em ordenar a orla. Trata-se da instituição no calendário da cidade do já citado 29 de dezembro como o Dia Oficial de Iemanjá. Assim, aquela divindade do candomblé e da umbanda, celebrada tradicionalmente na virada do ano, na Praia, através de oferendas e cerimônias que reuniam há muitos anos milhares de fiéis, e que na verdade deram origem ao hoje famoso mundialmente Réveillon de Copacabana, não competia mais com os festejos oficiais e turísticos, pagãos. Desta maneira, a festa de Iemanjá, divindade ligada às águas marinhas, passa a ser organizada por entidades privadas e pelo poder público, e não apenas por seus fiéis e comunidades religiosas .

É curioso observar que o dia dos festejos é mudado, porém isto não se traduz em grandes traumas para os fiéis; difícil imaginar coisa semelhante ocorrendo com outras tradições religiosas, ou seja, imaginar o Natal - nascimento de Jesus Cristo, para os cristãos - passando a ser comemorado no dia 23 de dezembro; ou o sábado de recolhimento da tradição judaica sendo mudado para o domingo, transferido de dia para que coubesse no calendário da cidade. Isto foi conseguido, pelo contrario, com demonstrações de apreço por vários devotos, pois para estes significou o reconhecimento oficial das crenças de matriz afro-brasileiras, perseguidas pelas forças 
policiais e por grupos de religiões majoritárias ao longo da história brasileira. Pareceu um preço a pagar que este reconhecimento trouxesse também o controle da festa por parte de entidades comerciais e pelos órgãos de segurança pública, e que sua organização não mais ficassse, como antes, por conta das mães e pais de santo dos diversos terreiros da cidade, no momento ritual da virada do ano.

Em 2009, a então recém-empossada gestão municipal do Rio de Janeiro organiza uma nova ofensiva, desta vez, contra o que chama de "ocupação ilegal de espaços públicos", e passa a reprimir desde estacionamentos em locais proibidos, passando pela população de rua até o comércio informal nas ruas e nas praias. A chamada Operação Choque de Ordem é promovida por uma nova Secretaria, a de Ordem Pública (Seop), chegando às areias da Zona Sul no início do verão daquele ano. Neste campo, esta operação inclui um pacote de proibições $^{10}$ e o monitoramento das atividades realizadas por banhistas e trabalhadores da praia. Cada ação, repetida periodicamente, conta com cerca de 140 agentes da Guarda Municipal e do Controle Urbano.

Neste contexto, a Prefeitura do Rio cria, em março de 2010, o Grupamento Especial de Praia, segmento da Guarda Municipal destinado a "patrulhar as praias da Zona Sul, desenvolvendo ações de assistência a banhistas e freqüentadores em geral", segundo informações do site da Prefeitura ${ }^{11}$. Ainda de acordo com o site, o grupamento se dedica a "coibir atos anti-sociais, fazendo cumprir o Código de Posturas Municipais",

10 Assim, a prefeitura a partir de então passa a proibir o uso de isopor, a manipulação de alimentos na areia, publicidade em cadeiras e guarda sóis, a prática de esportes na beira da água antes das $17 \mathrm{~h}$, o uso de botijão de gás, churrasqueira, ou qualquer aparelho elétrico ou de som, alimentos em palito, recipientes de vidro, a venda de bebidas não-industrializadas, estacionamento de veículo-depósito e presença de animais nas areias. Quanto às obrigações, os barraqueiros devem limpar a areia em volta da barraca, recolher o lixo ao fim do dia, usar uniforme padronizado, manter tabela de preços dos produtos em local visível e ter cesta de lixo com plástico descartável. Cf. "Operação Choque de Ordem reboca 56 veículos no Rio”, 2011.

${ }^{11}$ Cf. www.rio.rj.gov.br/web/gmrio/exibeconteudo?article-id=848165. Último acesso em 10/7/2015.

$3^{\text {RASILIANA- Journal for Brazilian Studies. Vol. 4, n.2 (2016). ISSN 2245-4373. }}$ 
lidando também com ocorrências como "crianças desaparecidas, afogamentos, furtos e prisões".

Em julho de 2011, outro grupamento da Guarda é criado, e também irá atuar no espaço da orla em diversas ocasiões. É o GOE -Grupamento de Operações Especiais, resultado da fusão de três grupamentos - dos guardas motociclistas (GGM), do Grupamento Tático Móvel (GTM) e o Grupamento de Ações Especiais (GAE), além de parte do Grupamento de Cães de Guarda (GCG). Identificados como a "tropa dos homens de preto" pela imprensa, quando de sua instalação ${ }^{12}$, por terem uniforme com esta cor, são responsáveis por agir em caso de "calamidade pública, salvamento e resgate". Ainda de acordo com o site, podem portar armas não letais, inclusive gás de pimenta, andam com "uniforme camuflado, capacete, escudo". Na época de sua criação, explicou-se no site que, desde que a Prefeitura havia lançado "um produto novo", a Unidade de Ordem Pública (UOP), havia necessidade de um grupamento que desse suporte a este novo contexto de atuação para a Guarda. Daí a criação do GOE ${ }^{13}$.

A mais tradicional força estadual a atuar nas praias é a dos Bombeiros militares, através dos Grupamentos Marítimos, compostos pelos "guarda-vidas" - denominação oficial dos popularmente conhecidos "salva-vidas"14. Estes, segundo o site do $3^{\text {o }}$ Grupamento Marítimo, responsável por Copacabana, são "habilitados a promover a segurança de vidas e o socorro e primeiros socorros às vítimas de afogamentos nas

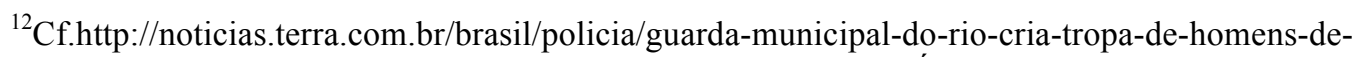
preto,2cb8325ab6e1b310VgnCLD200000bbcceb0aRCRD.html. Último acesso em 10/7/2015.

${ }^{13}$ Cf. www.rio.rj.gov.br/web/gmrio/exibeconteudo?article-id=2148463. Último acesso em 10/7/2015.

${ }^{14}$ Segundo o site do Corpo de Bombeiros Militares do Rio de Janeiro, existem quatro Grupamentos Marítimos que congregam os guarda-vidas: o de Botafogo, o de Copacabana, o da Barra da Tijuca e o de Itaipu, este último, na região oceânica de Niterói - cf. http://www.cbmerj.rj.gov.br/. Último acesso em 10/7/2015.
} 
praias, balneários, orla marítima, baías, lagos e rios no Estado do Rio de Janeiro", desenvolvendo "fiscalização preventiva" em toda a orla15.

Como se viu, as crescentes intervenções de vigilância e monitoramento igualmente supõem um grau cada vez maior de envolvimento do poder municipal no espaço público da cidade. É neste contexto que se pode entender melhor a criação, em 2010, do Centro de Operações Rio, da Prefeitura, que atualmente dispõe de 560 câmeras espalhadas por toda a cidade ${ }^{16}$.

Cabe notar que não só os órgãos de segurança ou do Estado vêem com crescente interesse a instalação do aparato audiovisual de monitoramento. Este padrão de segurança a partir da vigília pela captação de imagens vem se tornando mais e mais sedutor para outros segmentos, a reboque do aumento da sensação de insegurança na cidade e da atração pelo controle do espaço público por parte dos mais diversos agentes. Cardoso (2013) cita que, de 1998 a 2009, representantes eleitos para Assembléia Legislativa do Rio de Janeiro apresentaram 35 projetos de lei visando autorizar, regulamentar ou estabelecer câmeras de segurança em locais tão díspares quanto casas noturnas, maternidades, escolas, bancos e instituições carcerárias; sete destes foram aprovados. Enquanto isso, na Câmara Municipal, de 2001 a 2009, foram aprovados três projetos com o mesmo sentido (op. Cit.).

Além destas iniciativas no campo legislativo, há alternativas de vigilância e acompanhamento disponíveis. Assim, para qualquer um que se interesse em observar câmeras dispostas na orla carioca, basta acessar o domínio www.copacabana.com,

\footnotetext{
${ }^{15}$ Ver http://www.3gmar.cbmerj.rj.gov.br/modules.php?name=Content\&pa=showpage\&pid=191. Último acesso em 10/7/2015.

${ }^{16}$ Ver www.centrodeoperacoes.rio. Último acesso no dia 7/7/2015.
}

RRASILIANA- Journal for Brazilian Studies. Vol. 4, n.2 (2016). ISSN 2245-4373. 
gerenciado por UMRIO.net, e de lá acompanhar as "Câmeras ao vivo - Copacabana, Ipanema e Leblon"17.

Uma palavra cabe, ainda, para situar o momento desta segunda pesquisa. Tratouse justamente dos preparativos para dois grandes eventos esportivos para a cidade e o país: a Copa do Mundo de 2014 e as Olimpíadas de 2016. No caso do Rio de Janeiro, isto também envolve os notórios projetos de "revitalização" da cidade, como o do Porto Maravilha, criado a partir de Lei Municipal em 2009, em que a iniciativa privada se conjuga ao poder público para reestruturar o espaço público da região portuária da cidade do Rio de Janeiro, abrangendo uma área de 5 milhões de metros quadrados. As intervenções do poder público sobre a cidade incluem também um reordenamento do sistema de transporte e das vias públicas; remoções, em alguns casos e a urbanização, em outros, das favelas; ações de segurança pública, com o controle e ordenamento das atividades em comum em comunidades populares através da instalação das famosas Unidades de Polícia Pacificadora (UPPs), e também em espaços públicos da cidade, como no já citado "Choque de Ordem".

\section{Palco C: Domingão}

Visitar a praia do Posto Quatro num domingo de sol, em pleno verão, e verificar como o Choque de Ordem se apresente num cenário de normalidade na fruição da praia. Esta era a "missão". Já na caminhada do Posto 2 ao 4, três barracas instaladas na areia avisavam aos passantes e freqüentadores em letras gigantes: "Choque de Ordem Operação Verão". Entre o Posto 4 e o 5, era possível ver também um contêiner com a

\footnotetext{
${ }^{17}$ Último acesso: 7/7/2015.
}

3RASILIANA- Journal for Brazilian Studies. Vol. 4, n.2 (2016). ISSN 2245-4373. 
mesma inscrição, instalado na esquina de duas principais avenidas de Copacabana, próximo à orla.

Além dela e das barracas, vários veículos circulavam pela orla ostentando a mesma inscrição. Um deles, da Guarda Municipal, deixou alguns agentes na orla; outros guardas patrulhavam o calçadão usando patinetes elétricos. Enquanto isso, PMs andavam a pé pelo calçadão, de uniforme - alguns com camisa e bermuda, outros, com calça e camisa - e viaturas da corporação circulavam. Já os bombeiros salva-vidas, em dupla, dirigiam seu quadriciclo pela praia.

A praia estava cheia. No calçadão, quiosques padronizados; nas areias, barracas, algumas, também com estruturas iguais. Vendedores ambulantes carregavam suas mercadorias, que iam desde cangas e óculos a cremes, comidas, bebidas, acessórios diversos.

Enfim nos acomodamos na areia, escolhendo para isso um local próximo a uma das barracas do "Choque", onde havia três agentes da Guarda Municipal - mais precisamente, do GEP, conforme soubemos ao abordá-los para conversar. Um deles ouvia um rádio transmissor, para saber de possíveis ocorrências. Enquanto estávamos sentadas na praia, trabalhadores das barracas nos observavam. Alguns molharam nossos pés e perguntaram se gostaríamos de consumir algo.

O intenso movimento de pessoas na água e na areia foi se acalmando conforme a tarde avançava. Ao final, tanto os agentes quanto os trabalhadores pareciam menos atarefados, e pudemos entrevistar alguns deles. Os próprios freqüentadores se mostraram mais disponíveis após terem usufruído mais do espaço, e também conseguimos falar com eles. Entre estes, estavam moradores, banhistas habitantes de outros locais e municípios, e turistas, alguns deles estrangeiros. 


\section{Palco D: Os Agentes, a Gente}

Os agentes sociais mais relevantes, neste quadro, são, do lado da sociedade civil, os grandes empreendedores da iniciativa privada, a partir de redes de comércio de alimentos e do controle de parte dos empreendimentos locais e do entorno; os pequenos comerciantes - quiosqueiros, barraqueiros, ambulantes e trabalhadores locais; os banhistas e frequentadores, particularmente os turistas. Do outro lado, os representantes de órgãos do Estado e do Município - PMs, guardas municipais, bombeiros militares guarda-vidas. Neste contexto, cabe a pergunta: como esse Choque de Ordem vem sendo encarado pelos frequentadores e pelos agentes de ponta do poder público? E mais: de que ordem se trata?

A pesquisa indica que se estabeleceu uma divisão entre os apoiadores e os opositores do Choque. Dentre os apoiadores, além de obviamente os órgãos do poder público, conta-se boa parte dos banhistas e também os barraqueiros e os quiosqueiros donos das estruturas fixas de venda de alimentos e bebidas, cadastrados pela prefeitura. Para estes, era preciso mesmo organizar o negócio, garantir segurança, inibir conflitos, crimes, ilegalidades.

Sandra, barraqueira, 51 anos, diz que não tem "do que reclamar". "A gente passou a ser mais respeitado depois que a prefeitura passou a dar mais atenção pra gente.(...) Eu acho que o Choque é bom, porque a gente se sente seguro, lógico que é mais cobrado, é mais rígido, mas é só fazer as coisas certinho." Explica a ordem naquele espaço: “Enquanto eu tô aqui, eu considero como se fosse meu, então eu tenho que zelar pelo meu espaço, tá, tipo assim, não deixar sujo, tá, cuidar dos meus clientes. Então o choque termina que ajuda a gente." E completa, nos corrigindo: "não é barraqueiro, a palavra certa é empreendedor de ponto fixo da praia". Para a frequentadora Bárbara, a nova ordem é "a beleza que a padronização dos quiosques trouxe pra praia, o espaço 
organizado, o policiamento". "Beleza" é um critério que também dois turistas europeus, freqüentadores da praia, lembram ao explicar a Ordem do Choque. Para um deles, os ambulantes "enfeiam a paisagem, tem que chamar a policia, eles atrapalham os pedestres". E o outro completa: "as pessoas respeitam a força". Ambos elogiaram o policiamento e a padronização dos quiosques.

Dois entrevistados tem uma visão ligeiramente diferente do que ocorreu na orla, e sugerem a possibilidade de coexistência de duas ordens, a da sociabilidade local e a do poder público. Para um fiel que participou do evento Iemanjá, "a ordem é quando a prefeitura não impõe só leis, é quando também abre espaços como esse pra pessoas com crenças diferentes se expressarem". Uma moradora e frequentadora da praia de Copacabana lembra que "sempre foi bom, e ficou melhor depois do Choque. O policiamento está correto, tem que cumprir as leis." Neste contexto, ordem é entendida como controle do espaço e distribuição de tarefas, com a participação tanto do poder público quanto de quem trabalha e frequenta a orla.

Do lado dos opositores, uma parte dos vendedores ambulantes e uma pequena parte dos banhistas desconfiam que uma segurança ostensiva gera insegurança para a população frequentadora e trabalhadora; e que a nova ordenação apenas garante mais lucros para a prefeitura e para os grandes agentes privados.

Uma ambulante, Xauna, autodeclarada "índia", 45 anos, fala que o Choque de Ordem "é muito triste, (...) o problema principal é a Guarda Municipal. Eles não respeitam não. Sempre vem um guarda encher o saco, pressão, só botando pressão, já veio fiscal e falou assim 'ah, índia, você tem que ficar lá dentro do mato, não é na cidade grande não, mas eu não tô bagunçando, eu tô lutando meus direitos do meu espaço pra vender meu artesanato. Ele fala, 'você não pode expor aqui na calçada de Copacabana', eu posso, porque eu não tenho culpa do branco botar a calçada em cima da terra do índio, isso aqui antes de você chegar a gente tava aqui". Outro ambulante, vendedor de 
picolé, comenta: "Minha filha, não tem ordem pra pobre, trabalhador não tem direitos, é só ordem pros ricos. Para os turistas".

Um empregado de um quiosque é curto e grosso: “O choque de ordem é uma merda, desculpa a palavra, uma merda, os cara não sabe trabalhar, por que estão trabalhando? Eles chegam, não se apresentam, já vão pegando a mercadoria dos ambulantes, não dão recibo da mercadoria." Ele é cético também quanto à própria organização local: "é o que você ta vendo aí, não tem espaço, falta um banheiro, a pessoa toma cerveja, toma um chopp e faz as necessidades na praia, eu me sinto envergonhado com isso."

Notamos também uma certa má vontade dos próprios agentes encarregados de cumprir este Choque de Ordem. Assim, especialmente os salva-vidas, pertencentes ao Corpo de Bombeiros e portanto à Defesa Civil, vêem com bastante reservas a ação de outros grupos sobre o que consideram seu território (como no já citado "evento Iemanjá"). Também membros da Guarda Municipal se queixam de não saberem exatamente as competências de cada um - PMs, salva-vidas e eles próprios; de terem sido sobrecarregados com mais uma tarefa; da intromissão de outros agentes em suas missões.

Um PM entrevistado, apesar de afirmar que gosta de trabalhar na orla, também desconfia da ação pública tal como está sendo executada. “Ordem pra mim seria o trabalhador ter seus direitos, seu salário decente pra viver bem, e não só ser cobrado". Reclamou da imprensa, que, segundo ele, "só mostra o policial corrupto, não sabendo das condições da vida dele - não que isso justifique, mas cada profissional é um profissional".

Um agente do GEP - Grupamento especial de praia explica: “Antigamente pra trabalhar na praia a gente vinha como voluntário. Agora, depois da 1ํㅡㄹ Operação Verão, o profissional é selecionado a partir de um perfil". Segundo eles, tem que atuar um $3^{\text {RASILIANA- Journal for Brazilian Studies. Vol. 4, n.2 (2016). ISSN 2245-4373. }}$ 
pouco como os "salva-vidas", que para eles são "profissionais da polícia civil" (sic). No meio da entrevista, recebeu pelo rádio um chamado, por uma ocorrência de uma criança perdida na praia e foi atender. Segundo ele, atendia casos como proibição de alguns esportes na praia, como soltar pipa ou frescobol; cão na areia; delitos; e comércio irregular. Outro entrevistado do GEP comentou que, depois de 2009, com o Choque de Ordem, o grupamento que antes só patrulhava a Praia do Flamengo agora intervém em toda a orla da zona sul, até o Recreio. Acrescentou que o GEP também age em caso de realização de primeiros socorros. Nas entrevistas com estes agentes, ficou nítido seu desconhecimento sobre a atuação de outros profissionais da segurança particularmente os "salva-vidas", que são ligados à Secretaria de Defesa Civil - não a de Polícia Civil. A superposição de funções também parece estar sugerida no próprio site da Guarda, pois tanto este quanto o site do Corpo de Bombeiros estampa como "suas" funções o atendimento de casos de afogamento e de crianças desaparecidas.

Um agente do GOE relata que, ao realizar o controle dos ambulantes, está exercendo a função de outros trabalhadores, os fiscais da Prefeitura, "que inclusive prestaram concurso" para o cargo. Enfatiza que seu trabalho é a organização do trânsito, acompanhando carreatas e escoltas, e não trabalhar na repressão e na apreensão das mercadorias dos ambulantes. Estes conflitos, numa função que não entende como sua, o incomodam bastante. E resume: "ou eu salvo vidas ou guerreio nas ruas." Desencantado, tem resistido a atuar contra os ambulantes ilegais; "eles estão ganhando o pão. Tem que tirar a polícia militar de dentro da guarda municipal, a PM é que tem que patrulhar a orla."

Nesta visão, "ordem" é um rígido controle "desorganizado", com justaposição de poderes, conflitos com os locais e imposição arbitrária de poder, sem participação nem mesmo daqueles encarregados de mantê-la: os próprios agentes. 
Em suma, em relação a qual ordem se estabelece, o que se pode observar é que há dois significados diferentes em operação - um diz respeito à noção de ordem como algo tradicionalmente instituído a partir da sociabilidade local; outro, relacionado à nova ordem do Choque, recém-estabelecida pelo poder público naquele local. Assim, mais de 10 anos depois da primeira pesquisa, me deparei novamente com um termo em disputa - não mais democracia, mas "ordem". Desta feita, não havia, porém, uma pluralidade de perspectivas, mas duas: uma "ordem" calcada na segmentação e na organização social de freqüentadores, trabalhadores e demais moradores da cidade, e uma "ordem" calcada em diretrizes das instituições do poder público ligadas à área da segurança pública.

\section{Espaço público e esfera pública, hoje}

A relação que as diferentes sociedades desenham com seu espaço urbano preocupa estudiosos de diversas áreas. No campo das Ciências Sociais, são clássicas, e até hoje pertinentes, as observações que Park (1967), por exemplo, faz sobre a formação do que chamou de territórios "morais" na cidade, ou seja, locais simbolicamente configurados como área de exercício de determinada atividade e portanto dotada de uma sociabilidade específica do grupo que ali desenvolvia suas práticas. Da mesma forma, Guattari (1993) sinaliza a territorialidade como uma dimensão da identidade ligada ao espaço vivido, em que um determinado grupo social se sente "em casa".

Então, começando com este eixo de questões, é preciso começar esclarecendo que tomo aqui a definição de espaço público tal como é colocada por Goffman (2010), como “territórios não privativos", ou seja, como determinados locais de uma comunidade em que, segundo ele, o acesso é franqueado a todos. Desta forma, neste conceito não está envolvida a centralidade da ação política; dito de outra forma, estes locais podem ou 
não estar permeados por discussões, manifestações ou negociações de direitos, deveres e consensos.

As ações sobre as cidades se alicerçam em um modelo de espaço público que se conjuga ao de esfera pública; assim, quando se ordena o espaço, pensa-se em ordenar opiniões, atitudes e movimentos coletivos. Lembrando Habermas (2003), a noção de esfera pública deve ser situada dentro do campo do debate sobre representações e práticas políticas coletivas, da construção de consensos a respeito de ações que afetem a vida dos grupos em sociedade. Nesta direção, a esfera pública se coloca como dimensão de mediação entre a vontade de um Estado-nação e daquilo que constituiria a "sociedade civil", uma ponte entre Estado e comunidade que se caracterizaria pela apresentação e discussão dos desejos e ações dos diversos grupos sociais vis-à-vis seus representantes no aparelho de Estado.

$\mathrm{Na}$ área dos estudos urbanísticos, as noções de espaço público e esfera pública parecem quase se confundir, a ponto de Abrahão (2008), por exemplo, sugerir que as intervenções urbanísticas ao longo do século XX tinham como uma questão central responder a demandas de cidadania, democracia e participação social. Assim, deste ponto de vista, intervir na arquitetura da cidade era não apenas garantir a possibilidade de uma "ordem democrática", mas construí-la. Em outras palavras, a instituição de um espaço público corresponderia à constituição da esfera pública. Para o autor, também ele urbanista,

“ atribuía-se, assim, à materialidade destes espaços, uma realização sociopolítica identificada por atributos de concepções de espaço público - tais como cidadania, vida pública e direitos - formulados em outras esferas do conhecimento." (p. 16) 
Freeman (2002a, 2002b), geógrafo, resenha a discussão sobre espaço público, a partir do princípio do declínio da esfera pública nas grandes cidades contemporâneas. O recrudescimento da fruição da vida em âmbito privado, sob o embalo do lazer via computador e alta tecnologia e do medo generalizado diante do aumento da pobreza e da precariedade dos equipamentos urbanos são citados como forças motrizes para a desmobilização em relação à ocupação dos espaços públicos e ao mesmo tempo ao convívio e discussão coletiva das diferenças. No entanto, sinaliza que se o debate apenas se situar dentro destes moldes, haverá dificuldades para se compreender mais amplamente o que ocorre em espaços públicos do Rio de Janeiro, como suas praias e ruas.

Neste sentido, é curioso cotejar, por exemplo, o pressuposto do declínio do espaço público urbano ao que indica outra investigação, desta vez, antropológica, sobre o significado da rua - e também da casa - no universo da cultura brasileira. Da Matta (1991) nos fala de uma rua identificada com outro leque de sentidos; aqui, este espaço público urbano se conectaria ao desconhecido, e daí ao perigoso, ao contrário do espaço da casa, o refúgio da insegurança e do anonimato das cidades. A casa e a rua, além disso, se articulariam em uma disposição espacial que remeteria à própria constituição do urbano no Brasil; segundo ele, aqui, a demarcação espacial e social se faz sempre no sentido de uma gradação ou hierarquia entre centro e periferia, dentro e fora."(p. 36).

Estes espaços estão relacionados a lógicas diferentes, a visões de mundo que não se excluem, ainda segundo o autor, mas se complementam. Assim, a "rua" estaria articulada ao individualismo ocidental, a regras e normas sociais -representadas pelo poder público, em última instância, enquanto a casa estaria subsumida às dinâmicas das relações interpessoais, de parentesco. Entretanto, estas duas lógicas teriam pesos diversos na perspectiva brasileira, estando o familiar sobreposto à lógica "pública". 
Sem serem excludentes, tais visões de mundo dariam suporte também a tentativas de aproximações, de modo que determinados espaços "da rua" estariam passíveis de apropriações pela "lógica da casa". Daí por exemplo a instituição de territórios "familiares" em determinados pontos urbanos, onde segmentos específicos se considerariam e sem "sentiriam em casa".

A dinâmica destas aproximações poderia bem ser posta em diálogo com a perspectiva de outro estudioso brasileiro da vida nas cidades. Do ponto de vista de Magnani (2004, 2005), os grupos sociais tenderiam a se apropriar de territórios urbanos, demarcando sua ligação com eles, a partir da noção de "pedaço". Este "pedaço" seria justamente aquele território mais próximo da lógica da casa, inclusive espacialmente ligado ao local de moradia, onde se desenvolveria um tipo de relação intermédia entre o anonimato das grandes cidades e a familiaridade da casa. Este terreno se constituiria socialmente a partir da presença regular não só dos parentes mais próximos, como a casa, mas também do círculo dos vizinhos e de conhecidos de longa data.

O que parece estar em jogo nestas articulações de sentido propostas pelos autores acima citados é a construção do pertencimento à cidade, segundo, porém, movimentos distintos. Assim, se de um lado o segmento formado por urbanistas, políticos e gestores aposta numa conformação do urbano de acordo com a lógica da "polis grega", do individualismo ocidental regido pelos direitos e deveres comuns e representado pelo poder público, outros segmentos urbanos operam expandindo a lógica da consanguinidade, da familiaridade para além da "porta da rua". A disputa de sentidos sobre o que é a cidade e a vida urbana é portanto o pano de fundo para a discussão teórica acima ensaiada.

No entanto, esta disputa não se dá entre iguais em poder; pelo contrário, é marcada pela distribuição desigual de capitais econômicos e simbólicos, para recuperar aqui as interessantes assertivas de Bourdieu (2001). O "campo" do urbano é perpassado 
por lutas pelo poder, inclusive pelo poder de dar significado ao espaço. Neste sentido, as intervenções dos gestores, os planos urbanos, conformam a cidade numa escala maior, conectando-a com outras lógicas urbanas e permitindo inclusive que se configure aquilo que chamamos de "nação". As "leis gerais", como a Constituição, os Planos Nacionais e outros são expressões desta lógica e desta força, que no entanto, como vimos, sempre será relativizada e estará em diálogo com outras forças sociais que conformam territórios: as dos grupos que ali vivem.

Em 2011, quando inicio a pesquisa, o panorama das discussões acadêmicas sobre a cidade - meu primeiro eixo - dava conta do declínio do espaço público. Desta forma, a ocupação de praças e ruas e na mesma direção a expressão da vontade coletiva através desta ocupação, eram consideradas "coisas do passado". Impulsionada basicamente por crises econômicas, altos índices de criminalidade e violência urbana, pela desconfiança na ação política tradicional e principalmente pelo lazer proporcionado pela nova onda tecnológica, a assim chamada "nova cultura indoors" se definia pela comunicação online, pela permanência em casa e pela rejeição da circulação e uso político das ruas. Do meu canto do mundo, me parecia que havia algum sentido nisso. O aumento vertiginoso do uso das redes sociais, dos games, da insegurança e da violência urbana também era sentido no Brasil; o refluxo da movimentação política - comícios, showmícios, passeatas - nas ruas e praças também fazia parte do cenário brasileiro.

Entretanto, exatamente em 2011, com a chamada Primavera Árabe (iniciada naquele ano), os movimentos dos Indignados espanhóis, as manifestações na Grécia contra a política econômica de seu governo, e os diversos Occupy espraiados pelo mundo $^{18}$, foi possível indicar que a decretação da morte do espaço público e de sua conjugação à idéia de esfera pública eram prematuras. Nacionalmente, vimos crescer a

\footnotetext{
${ }^{18}$ Sobre o assunto, ver, por exemplo, Harvey et.al. 2012.
}

$3^{\text {RASILIANA- Journal for Brazilian Studies. Vol. 4, n.2 (2016). ISSN 2245-4373. }}$ 
volta às ruas a partir das manifestações que se iniciaram com protestos contra o aumento da tarifa no transporte público e se tornaram massivas expressões populares, as conhecidas “jornadas de junho" de 2013. Para além destes movimentos mais gerais, verificamos também a construção de ações periféricas, como o Ocupa Alemão e o Ocupa Maré, entre outras, que tentam canalizar as reivindicações de seus moradores para sua expressão em cenário público, em seus próprios locais de moradia.

Enfim, temos, do ponto de vista dos estudos urbanos, um recrudescimento da conexão entre espaço público e esfera pública, através do aumento da participação política nestes espaços. A gestão da segurança pública nestes espaços, no contexto das manifestações, porém, sugere o recurso a atitudes altamente repressivas e violentas e pouca habilidade no trato com os manifestantes, complementando o cenário. Vimos crescer também o recurso a instrumentos de vigilância do espaço por parte do poder público.

No caso do Choque de Ordem, objeto de nosso estudo, parece que, para além de resistências localizadas ${ }^{19}$, a imposição da "ordem" institucional, e nela embutida a idéia de força, medo e punição, foi conseguida. Vigora então uma vigilância e uma organização maior do espaço público praia, do ponto de vista dos agentes públicos, embora a confusão de competência siga sendo um ponto fraco neste processo de ordenamento institucional.

Desta maneira, o "Choque" e sua "ordem" parecem ter significado um "combate à outra ordem", a do consenso estabelecido pelos grupos nesses cenários ou palcos onde

\footnotetext{
${ }^{19}$ Barraqueiros e demais vendedores, principalmente, tprotestaram durante o verão de 2009 contra a ação de policiais e guardas municipais. Cf. http://g1.globo.com/Noticias/Rio/0,,MUL1042251-5606,00-

MANIFESTANTES+PROTESTAM+CONTRA+CHOQUE+DE+ORDEM+DA+PREFEITURA+DO+RIO.html; cf. também

http://www.sidneyrezende.com/noticia/67448+barraqueiros+protestam+contra+choque+de+ordem + nas + praias + nesta +segunda+feira. Último acesso: 8/7/2015.
}

3RASILIANA- Journal for Brazilian Studies. Vol. 4, n.2 (2016). ISSN 2245-4373. 
se movem, vivem e trabalham. A conexão entre estas duas ordens não é fácil, unívoca nem automática e, no quadro atual, parece bastante frágil.

A questão se torna então saber qual grau de diálogo será possível inventar e manter entre os diferentes agentes e suas "ordens", como alguns entrevistados sugeriram, ao frisar a possível complementaridade entre o que os planos propunham e as necessidades dos freqüentadores e trabalhadores da orla. Nesta chave de interpretação, o espaço público se construiria na negociação de ordens e democracias, numa trama de vontades coletivas. O diálogo e o consenso, assim, estariam pressupostos ao se conversar sobre ordem, conjugando de alguma forma, novamente, espaço e esfera pública. No entanto, num espaço público constantemente sob vigilância, numa esfera pública em que a "ordem" estatal é "de choque", até que ponto a polifonia é possível?

\section{Referências Bibliográficas}

Abrahão, Sérgio Luís. 2008. Espaço público - do urbano ao político. São Paulo, Fapesp/AnnaBlume.

Bourdieu, Pierre. 2001. 4ª Ed. O poder simbólico. Rio de Janeiro, Bertrand Brasil.

Cardoso, Bruno. 2013. "Câmeras legislativas: videovigilância e leis no Rio de Janeiro". In: Revista Brasileira de Ciências Sociais, v. 28, n. 81, SP, Anpocs.

DaMatta, Roberto. 1991. $4^{\mathrm{a}}$ Ed. A casa e a rua. Rio de Janeiro, Guanabara Koogan.

Farias, Patrícia.2003. Pegando uma cor na praia: relações raciais e classificação de cor na cidade do Rio de Janeiro. Prefeitura do Rio/Secretaria das Culturas. 
- Cecchetto, Fátima. 2009. “Tu mora onde? Território e produção de subjetividade no espaço urbano carioca". In: Sá Carneiro, Sandra de; Sant'anna, Maria Josefina Gabriel, Cidade: olhares e trajetórias, Rio de Janeiro, Garamond/Faperj.

Freeman, James. 2002a "Democracy and Danger on the Beach: Class Relations in the Public Space of Rio de Janeiro". In: Space and Culture, the Journal, 5 (1):9-28.

2002b. Face to Face but Worlds Apart: The Geography of Class in the Public Space of Rio de Janeiro. , University of California, Berkeley, 2002b.

Goffman, Erving. 2010. Comportamento em lugares públicos. Petrópolis, Vozes.

GOVERNO DO BRASIL/UNCED-RIO. Information for delegations. 1992. Rio de Janeiro: Governo Federal (publicação interna).

Guattari, Félix; Rolnik, Suely. 1993. Micropolítica-cartografias do desejo. Petrópolis, Vozes.

Habermas, Jürgen. 2003. Mudança estrutural da esfera pública. Investigações quanto a uma categoria da sociedade burguesa. Tempo Brasileiro.

Harvey et. al. 2012. Occupy - movimentos de protestos que tomaram as ruas. São Paulo: Boitempo/Carta Editoria.

Magnani, José Guilherme Cantor. 2004. 3a Ed. Festa no pedaço - cultura popular e lazer na cidade. São Paulo, Hucitec.

.2005. Os circuitos dos jovens urbanos. In: Tempo Social, v. 17, n. 2, pp.173-205, São Paulo, USP, novembro.

Mello, Kátia Sento Sé. 2011. Cidade e conflito - Guardas Municipais e camelôs. Niterói: Eduff.

Park, Robert Ezra. 1967. “A cidade: sugestões para a investigação do comportamento humano no meio urbano."In: Velho, Octávio (org.), O fenômeno urbano. Rio de Janeiro: Zahar, pp. 29-72. 
Reginensi, Caterine. 2008. Rio de Janeiro, cidade espetáculo - o projeto Orla Rio: que sustentabilidade é essa? In: Gomes, Maria de Fátima Cabral M.; Fernandes, Lenise Lima; Maia, Rosemere Santos, Interlocuções urbanas: cenários, enredos e atores, Rio de Janeiro, Faperj/Arco-Íris, pp. 141-160.

Robinson, Eugene. 1999. "On the beach at Ipanema". In: The Washington Post Magazine, August 1, p. 8-13, 21-24.

Turner, Victor. 1969. The ritual process - structure and anti-structure. Chicago, Aldine Publishing Co.

\section{Hemerografia}

CONSTITUIÇÃO DA REPÚBLICA FEDRATIVA DO BRASIL DE 1988. In: www.planalto.gov.br/ccivil_03/constituicao/constituicaocompilado.htm.

“Operação Choque de Ordem reboca 56 veículos no Rio”. In: http://g1.globo.com/Noticias/Rio/0,,MUL964547-5606,00OPERACAO+CHOQUE+DE+ORDEM+REBOCA+VEICULOS+NO+RIO.html 20/01/2009. Acesso em 4 de março de 2011.

http://g1.globo.com/Noticias/Rio/0,"MUL1042251-5606,00MANIFESTANTES+PROTESTAM+CONTRA+CHOQUE+DE+ORDEM+DA+PREFEITU RA+DO+RIO.html Último acesso em 8/7/2015.

http://www.sidneyrezende.com/noticia/67448+barraqueiros+protestam+contra+choque+ de+ordem+nas+praias+nesta+segunda+feira. Último acesso em 8/7/2015.

http://noticias.terra.com.br/brasil/policia/guarda-municipal-do-rio-cria-tropa-dehomens-de-preto,2cb8325ab6e1b310VgnCLD200000bbcceb0aRCRD.html. Último acesso em 10/7/2015.

www.centrodeoperacoes.rio. Último acesso em 8/7/2015.

www.copacabana.com/câmeras. Último acesso em 8/7/2015.

www.cbmerj.rj.gov.br. Último acesso em 10/7/2015. 
www.mercadaodemadureira.com. Último acesso em 9/7/2015.

www.rio.rj.gov.br/web/gmrio/exibeconteudo?article-id=848165. Último acesso em $10 / 7 / 2015$.

www.rio.rj.gov.br/web/gmrio/exibeconteudo?article-id=2148463. Último acesso em 10/7/2015. 